\title{
Endodontic medicine: interrelationships among apical periodontitis, systemic disorders, and tissue responses of dental materials
}

Luciano Tavares Angelo CINTRA ${ }^{(a)}$ Carlos ESTRELA(b)

Mariane Maffei AZUMA ${ }^{(c)}$ Índia Olinta de Azevedo QUEIROZ(a) Toshihisa KAWAI ${ }^{(d)}$

João Eduardo GOMES-FILHO(a)

(a) Universidade Estadual Paulista - Unesp, School of Dentistry, Department of Endodontics, Araçatuba, SP, Brazil.

(b) Universidade Federal de Goiás - UFG, School of Dentistry, Department of Stomatologic Sciences, Goiânia, GO, Brazil.

(c) University of Michigan, Department of Cariology, Restorative Sciences and Endodontics, Ann Arbor, MI, United States.

(d) NOVA Southeastern University College of Dental Medicine, Department of Periodontology, Fort Lauderdale, FL, United States.

Declaration of Interests: The authors certify that they have no commercial or associative interest that represents a conflict of interest in connection with the manuscript.

\section{Corresponding Author:}

Luciano Tavares Angelo Cintra

E-mail: lucianocintra@foa.unesp.br

https://doi.org/10.1590/1807-3107bor-2018.vol32.0068

Submitted: May 06, 2018

Accepted for publication: May 29, 2018

Last revision: June 08, 2018
Abstract: Endodontic medicine, which addresses the bidirectional relationship between endodontic infections and systemic diseases, has gained prominence in the field of endodontics. There is much evidence showing that while systemic disease may influence the pathogenesis of endodontic infection, endodontic infection can also cause systemic alterations. These alterations include more severe bone resorption and inflammation in the periapical area as well as enhanced systemic disease symptoms. Similarly, many reports have described the impact of systemic diseases on the tissue responses to dental materials. Conversely, the local use of dental materials may show systemic effects in the form of altered production of biomarkers. Thus, studies to better understand the mechanisms related to those connections are extremely important. In this context, the objective of this review was to analyze and discuss the current literature regarding the connections among these three factors-systemic diseases, endodontic infection, and endodontic dental materials-and determine how these connections may interfere in the systemic health status and the endodontic treatment outcomes, which are represented by periapical wound healing.

Keywords: Endodontics; Periapical Periodontitis; Dental Pulp Necrosis; Metabolic Diseases; Dental Materials.

\section{Introduction}

Endodontic infection may be described as bacterial colonization of the root canals, which occurs because of pulp exposure caused primarily by caries or dental trauma. Thus, apical periodontitis (AP) is an outcome of endodontic infection and is characterized by bone degradation in response to intracanal bacterial infection. Bone loss occurs as a host defense mechanism against infection. ${ }^{1}$ In the AP scenario, several proinflammatory cytokines are produced locally to mediate the immune response. This "cytokine storm" is related to the inflammatory process, bone resorption, and development of $\mathrm{AP}^{2,3}$

$\mathrm{AP}$ is known to have multiple adverse effects, including pain, loss of bone support, and even loss of the tooth. However, many investigators have attempted to determine the consequences of AP since it is a 
focus of infection, i.e., it is connected with the body system through blood vessels. ${ }^{4,5}$ These studies have emphasized the role of AP in systemic alterations in addition to the obvious local inflammation. ${ }^{6,7}$ Consequently, studies have been performed to answer the following question: Does endodontic infection alter systemic health status?

Thus, one of the objectives of this review was to analyze and discuss the current literature regarding the bidirectional relationship between endodontic infection and systemic diseases. Endodontic therapy aims to eliminate endodontic infection through the removal of microorganisms from the root canal system by cleaning and shaping, ${ }^{8}$ in addition to promoting the re-establishment of periapical tissues by using an inert and biocompatible material. ${ }^{9}$ However, previous studies have already described that the chemical composition of endodontic materials can affect the inflammatory response and repair processes, ${ }^{10}$ and also interfere with systemic health since these materials release toxic substances. ${ }^{11,12}$

Although the relationship between AP and systemic disorders has already been documented, ${ }^{13,14}$ the tissue response to biomaterials depends on the immune response, ${ }^{15,16}$ so systemic disorders can alter immune function and affect the healing process. ${ }^{14}$ Moreover, irrespective of the systemic condition, endodontic materials should show satisfactory physicochemical and biological properties and also the ability to promote healing.

Therefore, the second objective of this review was to discuss both the systemic effects of endodontic materials and the correlation between systemic conditions and endodontic materials.

\section{Methodology}

In the present study, a search was performed in the PubMed online database to identify the available basic research articles, reviews, and case reports on the relationship between endodontic infection and systemic diseases or that between dental materials and systemic diseases. The search included only articles in endodontic area published in English in indexed dental or medical journals. The selected articles were included only when they were judged to contain relevant and pertinent information by the authors of this study.

\section{Systemic conditions and their relationship with apical periodontitis (Table 1)}

\section{Effects of endodontic infection on the normal systemic condition}

There are multiple studies identifying AP as a factor that can potentiate the symptoms caused by inflammatory diseases such as diabetes. ${ }^{6}{ }^{17-19}$ However, there is limited evidence in the literature showing AP as the primary cause of systemic disorders. Studies in humans and animals have been conducted in order to determine systemic molecular changes in the body of individuals with no systemic disorders, but with AP.

Some studies were performed to assess the possible influence of AP on insulin resistance, which can increase the risk of diabetes.

Astolphi et al..$^{20,21}$ used a rat model of AP induced by pulp exposure to show that the presence of AP may cause alterations in both insulin signaling and insulin sensitivity in serum and skeletal muscle, probably because of elevated plasma TNF-a levels. Moreover, Pereira et al. ${ }^{22}$ found that AP promoted an increase in macrophage infiltration, inflammatory pathway activation in muscle tissue, and serum concentrations of heat shock protein and lipopolysaccharide in rats.

Regarding systemic inflammatory markers, Cintra et al. ${ }^{7}$ performed a study using a rat model of pulp exposure-induced AP. The results showed that the presence of one AP focus did not alter the expression of proinflammatory cytokines systemically. However, the presence of four AP foci increased the serum levels of interleukin (IL)-6, IL-17, IL-23, and TNF- $\alpha$ and decreased the NO synthase levels. These results suggest that the inflammatory changes reflect the amount of local inflammation. In addition, Samuel et al. ${ }^{5}$ observed that the presence of four AP foci is related to an increase in the levels of leukocytes, lymphocytes, and TNF$a$, and a decrease in serum IL-4 levels. Moreover, Zhang et al. ${ }^{23}$ showed that AP elevated the levels of C-reactive protein (CRP), IL-2, and IL-6 in rat blood serum, causing reversible changes in the aortic arch, myocardium, and spleen as well as irreversible changes in the liver. The authors concluded that AP may trigger 
Endodontic medicine: interrelationships among apical periodontitis, systemic disorders, and tissue responses of dental materials

Table 1. Characteristics of the studies included in the Part I-systemic condition and its relationship with apical periodontitis.

\begin{tabular}{|c|c|c|c|}
\hline Authors (year) & Study type & Systemic condition & Effects \\
\hline Kohsaka et al. ${ }^{26}$ (1996) & Rats & Diabetes & Diabetes increases bone loss and inflammatory response of AP. \\
\hline Brito et al. ${ }^{39}$ (2003) & Humans & Diabetes & $\begin{array}{l}\text { Diabetes increases refractory lesions after endodontic treatment } \\
\text { in men. }\end{array}$ \\
\hline Fouad and Burleson ${ }^{38}$ (2003) & Humans & Diabetes & $\begin{array}{c}\text { Diabetes is associated with a reduced successful outcome after } \\
\text { endodontic treatment }\end{array}$ \\
\hline Iwama et al. ${ }^{27}$ (2003) & Rats & Diabetes & Diabetes increases bone loss and inflammatory response of AP. \\
\hline Segura-Egea et al. ${ }^{32}$ (2005) & Humans & Diabetes & Type 2 diabetes is associated with the prevalence of AP. \\
\hline Caplan et al. ${ }^{46}(2006)$ & Humans & Cardiovascular diseases & $\begin{array}{l}\text { AP is associated with cardiovascular diseases in patients under } \\
\qquad 40 \text { years old. }\end{array}$ \\
\hline Schulze et al. ${ }^{17}$ (2007) & Humans & Diabetes & AP alters insulin resistance. \\
\hline Segura-Egea et al. ${ }^{53}$ (2010) & Humans & Cardiovascular diseases & Endodontic infection associated with hypertension. \\
\hline Segura-Egea et al. ${ }^{54}(2011)$ & Humans & Cardiovalcular diseases & $\begin{array}{c}\text { AP and root canal treatment was higher in smoker hypertensive } \\
\text { patients. }\end{array}$ \\
\hline López-López et al. ${ }^{33}$ (2011) & Humans & Diabetes & $\begin{array}{c}\text { Diabetes is associated with the prevalence endodontic treatment } \\
\text { and AP. }\end{array}$ \\
\hline Marotta et al. ${ }^{34}$ (2012) & Humans & Diabetes & Diabetes is not associated with the prevalence of AP. \\
\hline Pasqualini et al. ${ }^{45}$ (2012) & Humans & Cardiovascular diseases & There is no correlation between AP and cardiovascular diseases. \\
\hline Astolphi et al. ${ }^{20}(2013)$ & Rats & Healthy & AP increases the insulin signaling in serum \\
\hline Cintra et al. ${ }^{41}(2013)$ & Rats & Diabetes & $\begin{array}{c}\text { Diabetes increases AP bone resorption. AP increases } \\
\text { triglycerides levels. }\end{array}$ \\
\hline Inchingolo et al. ${ }^{24}$ (2013) & Humans & Healthy & AP increases oxidative stress \\
\hline Cintra et al. ${ }^{28}(2014)$ & Rats & Diabetes & $\begin{array}{c}\text { Diabetes increases AP bone resorption. AP increases } \mathrm{HbAl} \\
\text { levels. }\end{array}$ \\
\hline Cintra et al. ${ }^{29}(2014)$ & Rats & Diabetes & $\begin{array}{l}\text { Diabetes increases AP bone resorption. AP increases serum } \\
\text { inflammatory cells. }\end{array}$ \\
\hline Cintra et al. ${ }^{30}(2014)$ & Rats & Diabetes & $\begin{array}{l}\text { Diabetes increases AP bone resorption. AP increases the } \\
\text { proinflammatory cytokine IL-17 in blood. }\end{array}$ \\
\hline Costa et al..$^{50}(2014)$ & Humans & Cardiovascular diseases & AP increases the risk to develop coronary artery disease. \\
\hline Astolphi et al. ${ }^{21}(2015)$ & Rats & Healthy & AP increases the insulin signaling in skeletal muscle. \\
\hline Gomes-Filho et al. ${ }^{60}(2015)$ & Rats & Hypoestrogenia & $\begin{array}{c}\text { Hypoestrogenism increases levels of the local regulators of both } \\
\text { osteoclastogenesis and angiogenesis }\end{array}$ \\
\hline Gomes-Filho et al. ${ }^{61}$ (2015) & Rats & Hypoestrogenia & Hypoestrogenism potentiates the progression of AP \\
\hline Sánchez-Domínguez et al. ${ }^{18}$ (2015) & Humans & Diabetes & AP increases $\mathrm{HbA} 1$ levels. \\
\hline An et al. ${ }^{51}(2016)$ & Humans & Cardiovascular diseases & Endodontic infection associated with cardiovascular diseases. \\
\hline Cintra et al. ${ }^{7}$ (2016) & Rats & Healthy & AP increases proinflammatory cytokines \\
\hline Gomes et al. ${ }^{49}(2016)$ & Humans & Cardiovascular diseases & Endodontic infection associated with cardiovascular diseases. \\
\hline Grønkjær et al. ${ }^{59}$ (2016) & Humans & Cirrhosis & $\begin{array}{c}\text { AP increases the prevalence of cirrhosis-related complications } \\
\text { such as ascites, hepatic encephalopathy, and/or variceal } \\
\text { bleeding. }\end{array}$ \\
\hline Lijestrand et al. ${ }^{4}(2016)$ & Humans & Cardiovascular diseases & Endodontic infection associated with cardiovascular diseases. \\
\hline Martins et al. ${ }^{48}(2016)$ & Rats & Cardiovascular diseases & $\begin{array}{l}\text { Hypertension did not alter AP progression. Hypertension } \\
\text { increases osteoclasts differentiation "in vitro". }\end{array}$ \\
\hline Rudranaik et al. ${ }^{37}$ (2016) & Humans & Diabetes & $\begin{array}{c}\text { Diabetes increases the bone loss in AP and decrease the } \\
\text { healing capacity. }\end{array}$ \\
\hline Segura-Egea et al. ${ }^{40}(2016)$ & $\begin{array}{l}\text { Systematic } \\
\text { review and } \\
\text { meta-analysis }\end{array}$ & Diabetes & $\begin{array}{c}\text { Diabetes increases the prevalency of AP in endodontically } \\
\text { treated teeth. }\end{array}$ \\
\hline Zhang et al. ${ }^{23}(2016)$ & Rats & Healthy & $\begin{array}{c}\text { AP increases the levels of CRP, IL-2, and IL-6 in blood. In } \\
\text { addition, AP affects organs. }\end{array}$ \\
\hline
\end{tabular}

Continue 


\begin{tabular}{|c|c|c|c|}
\hline \multicolumn{4}{|l|}{ Continuation } \\
\hline Arya et al. ${ }^{19}(2017)$ & Humans & Diabetes & $\begin{array}{c}\text { Diabetes decreases periapical healing after endodontic } \\
\text { treatment. AP increases } \mathrm{HbAl} \text { levels }\end{array}$ \\
\hline Azuma et al. ${ }^{31}(2017)$ & Rats & Diabetes & $\begin{array}{c}\text { Diabetes increases interleukin- } 17 \text { levels in periapical, hepatic, } \\
\text { and renal tissues }\end{array}$ \\
\hline Cintra et al..$^{43}(2017)$ & Rats & Diabetes & AP alters body weight and weight of organs \\
\hline Khalighinejad et al. ${ }^{56}$ (2017) & Humans & Renal disease & $\begin{array}{l}\text { End-stage renal diseases may possibly alter the pathogenesis of } \\
\text { AP. AP increases the levels of urea. }\end{array}$ \\
\hline Khalighinejad et al. ${ }^{57}$ (2017) & Humans & Preeclampsia & AP is a strong predictor for maternal preeclampsia. \\
\hline Pereira et al. ${ }^{22}(2017)$ & Rats & Healthy & $\begin{array}{c}\text { AP promotes an increase in macrophage infiltration and } \\
\text { inflammation in muscle tissue }\end{array}$ \\
\hline Piras et al. ${ }^{58}(2017)$ & Humans & $\begin{array}{l}\text { Inflammatory bowel } \\
\text { disease }\end{array}$ & $\begin{array}{c}\text { Inflammatory bowel disease increases the prevalence } \\
\text { and bone loss of AP. }\end{array}$ \\
\hline Prieto et al. ${ }^{6}(2017)$ & Rats & Diabetes & $\begin{array}{l}\text { Diabetes increases AP bone resorption. } \\
\text { AP increase oxidative stress. }\end{array}$ \\
\hline Rashmi et al. ${ }^{47}(2017)$ & Humans & Cardiovascular diseases & AP alters systemic inflammatory markers in hypertensive patients. \\
\hline Smadi et al. ${ }^{35}$ (2017) & Humans & Diabetes & Diabetes is associated with the prevalence of AP. \\
\hline Singhal \& Rai ${ }^{44}$ (2017) & Humans & Cardiovascular diseases & AP alters systemic inflammation. \\
\hline Tibúrcio-Machado et al. ${ }^{36}$ (2017) & $\begin{array}{c}\text { Critical } \\
\text { literature } \\
\text { review }\end{array}$ & Diabetes & $\begin{array}{l}\text { Positive association between diabetes and a larger number of } \\
\text { periapical lesions. }\end{array}$ \\
\hline Fereira et al. ${ }^{42}(2017)$ & Rats & Diabetes & $\begin{array}{l}\text { Oral infections associated with diabetes increases } \\
\text { mean platelet count. }\end{array}$ \\
\hline Virtanen et al. ${ }^{52}$ (2017) & Humans & Cardiovascular diseases & AP is associated with cardiovascular diseases. \\
\hline Samuel et al. ${ }^{5}(2018)$ & Rats & Healthy & AP increases inflammatory cells in blood. \\
\hline
\end{tabular}

a systemic immune response, impair remote organs, and affect the general health of patients. ${ }^{23}$ In humans, Inchingolo et al. ${ }^{24}$ evaluated the impact of chronic apical periodontitis on oxidative stress. Oxidative stress is a "disturbance in the pro-oxidant-antioxidant balance in favor of the former, leading to a disruption in redox signaling and/or molecular damage." ${ }^{25}$ In this context, the authors conducted a study in which the oxidative balance in both patients with chronic AP and healthy control participants was determined by measuring the oxidant status using a test for identification of the reactive oxygen metabolites (d-ROMs), while the antioxidant status in these patients was determined using a biological antioxidant potential (BAP) test. The tests were conducted before endodontic treatment and 30 and 90 days after the treatment. The results showed that, on recruitment, patients with chronic AP exhibited significantly higher levels of oxidative stress than controls, as determined by the d-ROM and BAP tests. Furthermore, the d-ROM test values decreased and the BAP test values increased over time in patients with chronic AP following endodontic therapy. The levels of oxidative stress in these patients tended to reduce and return to normal by 90 days following treatment. ${ }^{24}$

It is possible to infer that studies on the impact of endodontic infection on systemic health have been increasing, which shows that it is very important to conduct more studies to better understand these connections and outcomes..

\section{Bidirectional relationship between systemic disorders and endodontic infection}

\section{a. Diabetes and endodontic infection}

Many clinicians and researchers have studied the interrelationship between oral infections and systemic disorders. The bidirectional relationship between endodontic infection and the systemic metabolic disease diabetes has been one of the targets of studies to better understand the connections between local and systemic inflammatory processes. It is well established that diabetes can influence the pathogenesis of $\mathrm{AP}$, especially its severity and development. 
The first paper describing the influence of diabetes on the pathogenesis of AP was published in 1996 by Kohsaka et al., ${ }^{26}$ which showed that inflammation in the periodontal ligament of the periapical area, root resorption, and bone alveolar loss were more severe in diabetic rats compared to the control group. Consequently, lesions in the periapical area were larger in diabetic rats compared to those in the control group. ${ }^{26}$ Subsequently, other animal studies ${ }^{6,27-31}$ comparing the severity of inflammation and periapical bone loss between patients with diabetes and normoglycemic controls were conducted and are in agreement with the findings obtained by Kohsaka et al. ${ }^{26}$ In addition, one of these studies showed that diabetes may enhance the production of IL-17 in the AP site of rats, ${ }^{31}$ confirming that diabetes may influence the inflammatory process in periapical tissues of rats with endodontic infection.

In humans, several studies have been performed in order to study the correlation between the prevalence of AP and diabetes. Segura-Egea et al. ${ }^{32}$ performed a retrospective study using the records of 38 diabetic and 32 normoglycemic subjects. Their study showed $\mathrm{AP}$ in at least one tooth in $81.23 \%$ of diabetic patients and $58 \%$ of control subjects. The authors concluded that type 2 diabetes mellitus is significantly associated with an increased prevalence of AP. Later, LópezLópez et al. ${ }^{33}$ performed a cross-sectional study using the radiographic records of 50 diabetic patients and 50 normoglycemic subjects. The results showed that AP in one or more teeth was present in $74 \%$ of diabetic patients and $42 \%$ of control subjects. Among diabetic patients with root-filled teeth, $46 \%$ had AP affecting at least one treated tooth and $24 \%$ of the controls had AP affecting at least one treated tooth. After adjusting for teeth number, multivariate logistic regression analysis showed that periapical status and the number of rootfilled teeth were significantly associated with diabetic status. In addition, Marotta et al. ${ }^{34}$ conducted a crosssectional study that showed that AP was significantly more prevalent in untreated teeth from patients with type 2 diabetes. According to the authors, diabetes may serve as a disease modifier of AP in the sense that individuals with diabetes can be more prone to develop primary disease. In agreement with the previous studies, $\mathrm{Smadi}^{35}$ found that there is a higher prevalence of AP in diabetes mellitus patients compared with that in the nondiabetic group, with an increased prevalence of persistent chronic AP. In comparison with well-controlled diabetes, poor glycemic control may be associated with a higher prevalence of AP and an increased rate of endodontic failures. Despite the results correlating the higher prevalence of AP with diabetic status, Tibúrcio-Machado et al., ${ }^{36}$ in a critical review, concluded that the results presented in the literature were still scarce and incipient and the evidence for such an association was not yet conclusive. However, the published results trend to converge on a positive association between diabetes and a larger number of periapical lesions. ${ }^{36}$

Regarding the severity and lesion size, Rudranaik et al. ${ }^{37}$ concluded that diabetic patients with chronic AP have larger lesions and delayed healing outcomes when compared to normoglycemic patients.

In order to obtain a more precise prognosis of endodontic treatment in diabetic patients, many studies have been performed to compare the healing outcomes after conventional endodontic treatment between diabetic and normoglycemic patients. Fouad and Burleson ${ }^{38}$ performed conventional endodontic treatment in 284 diabetic patients and followed up 73 of them for two years postoperatively. Patients with diabetes showed increased periodontal disease of teeth with endodontic involvement compared with normoglycemic patients. There was a trend toward increased symptomatic periradicular disease in patients with diabetes who received insulin, as well as flare-ups in all diabetic patients. In addition, the presence of diabetes was associated with significantly reduced successful outcomes. ${ }^{38}$ Moreover, Brito et al. ${ }^{39}$ evaluated the records of 30 diabetic individuals and 23 control subjects and found that men with type 2 diabetes who received endodontic treatment were more likely to have refractory lesions after endodontic treatment. In accordance with these previous studies, Segura-Egea et al..$^{40}$ performed a systematic review and meta-analysis that showed that diabetic patients have a higher prevalence of AP in endodontically treated teeth. Thus, diabetes is an important putative pre-operative prognostic factor in root canal treatment. However, Marotta et al. ${ }^{34}$ performed a cross-sectional study that showed no significant difference between patients with and without diabetes when the prevalence of AP in 
root canal-treated teeth, the number of teeth in the oral cavity, the number of treated teeth per individual, the number of individuals with at least $1 \mathrm{AP}$ lesion or one root canal treatment, and the number of teeth with AP per individual were evaluated. Recently, Arya et al. ${ }^{19}$ observed that both the diabetic and nondiabetic groups showed a significant reduction in the periapical score after endodontic treatment at the 12-month follow-up. In addition, significantly less periapical healing was observed in the diabetic group (43\%) compared with the nondiabetic group ( $80 \%$ ) at the 12-month follow-up.

At present, studies have established that while diabetes can influence the pathogenesis of AP, AP can also potentiate the systemic effects occurring as a consequence of diabetes.

Schulze et al. ${ }^{17}$ presented a case report showing a sudden increase in patient blood glucose levels during exacerbation of a combined endodonticperiodontic lesion. Forty days after the endodontic treatment, the insulin dosage was comparable to that taken before the endodontic-periodontic lesion exacerbation. Thus, the authors concluded that there is a relevant correlation between insulin resistance and the presence of a local dental inflammation, which shows the importance of conventional endodontic treatment in the non-vital teeth of diabetic patients.

In addition, studies using animal models have shown that AP in combination with periodontal disease can potentiate the systemic effects of diabetes. These effects may be represented by an increase in triglyceride levels, ${ }^{41} \mathrm{HbA} 1 \mathrm{c}$ serum levels, ${ }^{28}$ proinflammatory cytokine IL-17 levels, ${ }^{30}$ inflammatory cells in the blood, ${ }^{29}$ and platelets. ${ }^{42}$ In addition, the studies showed that the associations among $\mathrm{AP}, \mathrm{PD}$, and diabetes increased the weights of the brain, heart, and gonads and the total body weight of rats. ${ }^{43}$ According to the authors, these results demonstrate that AP can affect the body system. ${ }^{43}$ Another study using an animal model showed how AP can affect the oxidative stress parameters in the presence of diabetes. ${ }^{6}$ The findings showed that AP might potentiate diabetes pathogenesis, increasing the levels of uric acid, which serve as a marker for chronic kidney disease. ${ }^{6}$ In addition, AP not only increases the levels of the antioxidant uric acid, but also decreases the levels of the antioxidant albumin, confirming that it can enhance the pathogenesis of diabetes.
The authors emphasized that these findings are very important because they suggest that the treatment and management of AP might improve the systemic oxidative condition induced by diabetes. ${ }^{6}$

In humans, Sánchez-Domingues et al. ${ }^{18}$ performed a cross-sectional study in which a worse periapical status was correlated with higher HbA1c levels in diabetic patients, supporting the findings of previous studies performed in animals. ${ }^{28}$ Arya et al. ${ }^{19}$ observed that $\mathrm{HbA1c}$ levels in diabetic patients increased at each follow-up examination after endodontic treatment.

Taken together, these studies strongly suggest a bidirectional relationship between endodontic infection and diabetes, highlighting the importance of endodontic treatment in improving systemic health condition.

\section{b. Cardiovascular diseases and endodontic infection}

Another possible systemic alteration linked to AP is cardiovascular disease, which has been intriguing many researches since few studies have addressed the association between them. These studies assessed the alterations represented by coronary artery disease, ${ }^{44,45,46}$ acute coronary syndrome, ${ }^{4}$ and hypertension. ${ }^{47,48}$

There are some studies in the literature that associated the presence of AP with cardiovascular diseases. Caplan et al. ${ }^{46}$ evaluated whether incident radiographically evident lesions of endodontic origin were related to the development of coronary heart disease (CHD) in 708 patients. The results showed a relationship between $\mathrm{AP}$ and $\mathrm{CHD}$ in patients aged under 40 years. These results were confirmed later by Gomes et al., ${ }^{49}$ who showed that the endodontic burden in midlife was an independent predictor of CVE among community-dwelling participants. However, Pasquilini et al. ${ }^{45}$ designed a case-controlled clinical trial using 51 patients with acute myocardial infarction or unstable angina and 40 healthy controls, which did not show evidence indicating a correlation between AP and CHD. Subsequently, Costa et al. ${ }^{50}$ performed a cross-sectional study including 103 patients who underwent coronary angiography and found that patients with chronic AP had a 2.79-fold higher risk of developing coronary artery disease. Moreover, An et al..$^{51}$ observed that subjects with AP were 5.3-fold more likely to have CVD than subjects without AP. In addition, Liljestrand et al. ${ }^{4}$ as well as 
Virtanen et al. ${ }^{52}$ concluded that AP is associated with cardiovascular disease. In addition, Lijestrand et al. ${ }^{4}$ concluded that AP is associated independently with CAD and, in particular, acute coronary syndrome, consolidating the role of oral conditions in evaluating total cardiovascular risk.

Regarding the association between hypertension and AP, Segura-Egea et al. found that hypertension is associated with the presence of $\mathrm{AP}^{53}$ and tobacco can increase that prevalence. ${ }^{54}$

Although there is evidence for the correlation between cardiovascular diseases and AP, more studies should be performed to better elucidate the mechanisms associated with those events. Rashimi et al. ${ }^{47}$ measured the levels of $\mathrm{CRP}$, which is a biomarker for cardiovascular diseases, as well as the proinflammatory cytokine IL-6 and fibrinogen. They found that in hypertensive patients, AP alters the systemic levels of inflammatory markers such as CRP, IL-6, and fibrinogen. In addition, another study demonstrated that elevated levels of the receptors sTNF-R1 and sTNF-R2, which are markers for the activity of the proinflammatory cytokine TNF- $\mathrm{a},{ }^{55}$ were found in periodontal disease patients, indicating an increased independent risk of CHD in these patients. ${ }^{44}$ Regarding the possible influence of cardiovascular diseases on AP progression, one study found that hypertension did not influence the expression of proinflammatory mediators or the periapical lesion size in mice. However, the hypertension group showed elevated osteoclast differentiation in vitro. ${ }^{48}$

In conclusion, there is evidence suggesting that endodontic infection and cardiovascular diseases are correlated. However, more studies should be conducted to better understand the pathways and possible targets related to those interactions, in order to control the consequences of both diseases.

\section{c. Other systemic disorders and endodontic infection}

Although diabetes and cardiovascular diseases are the most explored systemic disorders related to AP, other studies have been performed to determine the bidirectionality between AP and other systemic diseases.

Khalighinejad et al. ${ }^{56}$ performed a cross-sectional study to evaluate the presence of AP in patients with end-stage renal disease (ESRD) in comparison with that in patients with no history of ESRD. The results showed AP in $73 \%$ of patients with ESRD and in $40 \%$ of control patients. In addition, $52 \%$ of the patients with ESRD had at least one endodontically treated tooth, while the control group value was $28 \%$. Moreover, they found that the number of teeth with AP was significantly associated with the serum urea levels in the experimental group. The authors concluded that ESRD could possibly alter the pathogenesis of AP. However, these findings do not confirm the presence of any cause-and-effect relationship between these conditions. Nevertheless, considering the modifying effect of AP on serum urea levels, treatment of AP could be incorporated in the treatment planning of patients with ESRD. ${ }^{56}$

The same research group performed a study investigating the association between maternal AP and preeclampsia (PE) in patients. ${ }^{57}$ The results of this case-control study showed that AP in at least one tooth was found in 54\% of the mothers who develop PE in comparison with $16 \%$ of the mothers with a normal course of pregnancy. The authors concluded that this study provided evidence that maternal AP may be a strong independent predictor of PE. ${ }^{57}$ Piras et al. ${ }^{58}$ evaluated the prevalence of AP in patients with inflammatory bowel disease (IBD) treated with immunomodulators. In their study, the patients underwent a complete oral, dental, and radiographic examination. They found that women with IBD taking immunomodulators had a higher prevalence of AP. In addition, all patients with IBD had larger AP lesions than healthy subjects.

Grønkjær et al. ${ }^{59}$ observed the prevalence of AP in patients with cirrhosis and the association with systemic inflammation status and cirrhosis-related complications. The results revealed that patients with AP had higher CRP and lower albumin levels than those without AP. Furthermore, patients with AP showed a higher prevalence of cirrhosis-related complications such as ascites, hepatic encephalopathy, and/or variceal bleeding.

Gomes-Filho et al. ${ }^{60,61}$ showed that hypoestrogenia may stimulate osteoclastogenesis and osteoclast activity, increasing the levels of RANKL and inflammatory cells, during the progression of AP. As a consequence, hypoestrogenia potentiates bone resorption in the periapical tissues of rats with endodontic infection. 
Thus, these findings indicate that there are many possible bidirectional relationships between endodontic infection and systemic disorders. Although more studies should be performed to better comprehend these interactions, eradicating the focus of infection should be one of the goals to improve systemic health.

\section{Systemic conditions and their relationships with dental materials}

\section{Systemic effects of dental materials (Table 2)}

Dental materials are routinely used in dental practice, including direct restorative materials,

Table 2. Characteristics of the studies included in the Part II (a) - Systemic effects of dental materials.

\begin{tabular}{|c|c|c|c|c|}
\hline Authors (year) & Study type & Materials & Body organs & Analysis \\
\hline $\begin{array}{l}\text { Elovaara et al. }{ }^{69} \\
\text { (1983) }\end{array}$ & Rats & Methyl methacrylate (MMA) & $\begin{array}{l}\text { Kidney } \\
\text { Liver }\end{array}$ & $\begin{array}{l}\text { Biochemical analysis (NADPH-cytochrome c } \\
\text { reductase, 7-ethoxycoumarin 0-deethylase, } \\
\text { PPO, GSH, cytochrome P-450) }\end{array}$ \\
\hline Raje et al. ${ }^{70}$ (1985) & Rats & Methyl methacrylate (MMA) & $\begin{array}{l}\text { Blood } \\
\text { Brain } \\
\text { Lungs }\end{array}$ & $\begin{array}{l}\text { Histopathologic } \\
\text { Chromatography }\end{array}$ \\
\hline $\begin{array}{l}\text { Economides et al. }{ }^{76} \\
\text { (1995) }\end{array}$ & Rats & $\begin{array}{c}\text { AH-26 } \\
\text { Roth } 811 \\
\text { CRCS } \\
\text { Sealapex }\end{array}$ & $\begin{array}{l}\text { Brain } \\
\text { Liver } \\
\text { Kidney } \\
\text { Uterus }\end{array}$ & Biochemical analysis (Zn, Ca) \\
\hline $\begin{array}{l}\text { Kolokouris et al. }{ }^{77} \\
\text { (1998) }\end{array}$ & Rats & Roth 811 & $\begin{array}{l}\text { Liver } \\
\text { Heart } \\
\text { Kidney } \\
\text { Brain }\end{array}$ & Biochemical analysis $(\mathrm{Zn}, \mathrm{Ca}, \mathrm{Cu})$ \\
\hline $\begin{array}{l}\text { Ballestri et al. }{ }^{62} \\
(2001)\end{array}$ & Humans & Dental prostheses (porcelain) & $\begin{array}{l}\text { Liver } \\
\text { Kidney }\end{array}$ & Histopathologic \\
\hline $\begin{array}{l}\text { Al-Hiyasat et al. }{ }^{67} \\
(2002)\end{array}$ & Mice & $\begin{array}{l}\text { Dental composite } \\
\text { Resin Z-100 }\end{array}$ & Testicles & $\begin{array}{c}\text { Fertility } \\
\text { Sperm count }\end{array}$ \\
\hline $\begin{array}{l}\text { Fakhouri et al. }{ }^{68} \\
(2008)\end{array}$ & Rats & Methyl methacrylate (MMA) & $\begin{array}{c}\text { Testicles } \\
\text { Seminal vesicles }\end{array}$ & Histopathologic \\
\hline $\begin{array}{l}\text { Khalil and Eid }{ }^{65} \\
(2013)\end{array}$ & Rats & $\begin{array}{c}\text { Diaroot } \\
\text { Bioaggregate } \\
\text { Grey ProRoot MTA }\end{array}$ & $\begin{array}{c}\text { Blood (plasma) } \\
\text { Kidney } \\
\text { Liver }\end{array}$ & $\begin{array}{c}\text { Histopathologic } \\
\text { Biochemical analysis } \\
\text { (ALT,AST,Urea,Creatinine) }\end{array}$ \\
\hline $\begin{array}{l}\text { Demirkaya et al. }{ }^{11} \\
(2016)\end{array}$ & Rats & $\begin{array}{l}\text { MTA Angelus } \\
\text { MTA Fillapex } \\
\text { Theracal LC }\end{array}$ & $\begin{array}{l}\text { Blood (plasma) } \\
\text { Liver }\end{array}$ & Biochemical analysis (Al) \\
\hline Simsek et al. ${ }^{12}$ (2016) & Rats & $\begin{array}{l}\text { Micro Mega MTA } \\
\text { Bioaggregate } \\
\text { Biodentine }\end{array}$ & $\begin{array}{l}\text { Kidney } \\
\text { Liver }\end{array}$ & Biochemical analysis ( $\mathrm{Be}, \mathrm{Mg}, \mathrm{Al}, \mathrm{Ca}, \mathrm{Cr}, \mathrm{As}, \mathrm{Pb})$ \\
\hline $\begin{array}{l}\text { Demirkaya et al. }{ }^{64} \\
(2017)\end{array}$ & Rats & $\begin{array}{l}\text { MTA Angelus } \\
\text { MTA Fillapex Theracal LC }\end{array}$ & Brain & $\begin{array}{c}\text { Biochemical analysis (Al) } \\
\text { Oxidative stress (TBARS,CAT,SOD,GPx) }\end{array}$ \\
\hline $\begin{array}{l}\text { Demirkaya et al. }{ }^{73} \\
(2017)\end{array}$ & Rats & $\begin{array}{l}\text { MTA Angelus } \\
\text { MTA Fillapex Theracal LC }\end{array}$ & $\begin{array}{c}\text { Blood (erythrocytes) } \\
\text { Liver }\end{array}$ & Oxidative stress (TBARS,CAT,SOD,GPx) \\
\hline $\begin{array}{l}\text { Garcia et al. }{ }^{66} \\
(2017)\end{array}$ & Rats & MTAEndobinder & $\begin{array}{c}\text { Blood (plasma) } \\
\text { Kidney } \\
\text { Liver }\end{array}$ & $\begin{array}{l}\text { Histopathologic analysis; } \\
\text { Biochemical analysis } \\
\text { (ALT,AST,Urea,Creatinine) }\end{array}$ \\
\hline $\begin{array}{l}\text { Queiroz et al. }{ }^{80} \\
(2018)\end{array}$ & Rats & $\begin{array}{c}\text { Gray MTA Angelus white MTA } \\
\text { Angelus }\end{array}$ & Blood (plasma) & Biochemical analysis (Ca, P, ALP) \\
\hline
\end{tabular}


bonding materials, composites, acrylic resins, endodontic sealers, pulp-capping materials, root end-filling materials, and substances for release either into the oral environment or into body fluids. ${ }^{12,62,63,64}$ Thus, once these materials are in direct contact with dental tissues (dental pulp, cementum, alveolar bone, and the periodontal ligament), their chemical composition can interfere with and consequently affect the tissue response and repair process, ${ }^{10}$ and also compromise systemic health. ${ }^{12,64}$ Therefore, studies have been conducted to evaluate the potential risks of these materials to body organs. ${ }^{11,62,64,65,66}$

Al-Hiyasat et al ${ }^{67}$ suggested that leached substances from resin-based dental composite materials have an adverse effect on the fertility and reproductive system of male mice. Fakhouri et al. ${ }^{68}$ demonstrated that the administration of high concentrations of methyl methacrylate is associated with seminal vesicle atrophy in rats. In addition, higher concentrations of methyl methacrylate are also related to alterations or lesions in several organs, such as the liver, kidney, brain, and lung. ${ }^{69,70}$ Furthermore, Ballestri et al. ${ }^{62}$ assessed the presence of granulomatosis in the liver and kidney of patients with malocclusion, bruxism, and worn dental prostheses and suggested that the systemic foreign body granulomatosis found in these patients can be associated with worn dental prostheses, since the particles isolated from the liver-kidney granulomas contained feldspars, the main component of porcelain.

With respect to endodontic materials, it has already been described that endodontic sealers can release heavy metals ${ }^{71,72}$ even after setting. ${ }^{73}$ These metals/ ions can enter the bloodstream and be transported to distant tissue sites, which may leave traces on some organs and affect their metabolism..$^{11,12}$ The rate of element/ion release will vary considerably depending on the chemical composition, ionic dissolution, and setting time of the material. ${ }^{72,73,74,75}$

The first study reporting the impact of endodontic sealers on the concentrations of trace ions in body organs was performed by Economides et al. ${ }^{76}$ which verified the concentrations of zinc and calcium in the brain, liver, kidneys, and uterus of rats at 7 days after subcutaneous implantation of AH-26, Roth 811, CRCS, and Sealapex sealers, and reported that
AH-26 induced an increase in calcium levels and CRCS increased zinc concentrations in all organs examined, whereas the liver zinc concentration increased and calcium concentration in all body organs decreased in the presence of the Roth 811 sealer. Furthermore, Kolokouris et al. ${ }^{77}$ injected Roth 811 into the dorsal thoracic of rats and analyzed the zinc, calcium, and copper concentrations in the liver, heart, kidney, and brain. The authors verified the concentrations every day over 7 days and reported that the Roth 811 injections mainly on the $4^{\text {th }}$ and $5^{\text {th }}$ days, altered the zinc, calcium, and copper concentrations in body organs.

Khalil and Eid $^{65}$ noted that MTA promoted changes in the liver and kidney. The authors investigated and compared the systemic toxic effects of DiaRoot BioAggregate and ProRoot MTA on the liver and kidney 7 and 30 days after direct application to the connective tissue of rats and observed severe inflammatory reactions in the presence of both sealers, which decreased with time. Additionally, they analyzed serum alanine aminotransferase (ALT) and aspartate aminotransferase (AST) levels to assess liver function and urea and creatinine levels to verify kidney function. Kidney function was not affected, but a continuous increase in the liver function markers was detected in the presence of MTA. In a similar investigation, the systemic effects of MTA and EndoBinder were also evaluated in the liver and kidney by Garcia et al. ${ }^{66}$ They reported that both sealers caused severe inflammatory reactions in the body organs, but in the MTA group, these reactions were more accentuated. In addition, an increase in liver function marker levels was also detected in the presence of MTA.

Simsek et al. ${ }^{12}$ analyzed the levels of seven ions, namely, beryllium, magnesium, aluminum, calcium, chromium, arsenic, and lead, in the brain, liver, and kidneys of rats 45 days after implantation of Micro Mega MTA, Bioaggregate, and Biodentine materials in subcutaneous tissue, and demonstrated higher levels of chromium in the brain and kidney samples and magnesium in the kidney and liver samples. Chromium, in particular the hexavalent chromium, is a wellknown human carcinogen. ${ }^{78}$ Renal insufficiency 
and neuromuscular and cardiovascular toxicity can be linked to hypermagnesemia. ${ }^{79}$ However, even with the elevated levels of these metals in the brain, kidney, and liver samples, all sealers were considered nontoxic to these body organs, since the increase was below the toxic levels for trace elements.

The effects of both Gray and White MTA on systemic bone marker expression at 7 and 30 days after subcutaneous implantation in rats were investigated. Calcium, phosphorus, and serum alkaline phosphatase levels were measured, and the calcium and phosphorus levels increased at 7 days and decreased with time; however, alkaline phosphatase levels remained unaltered. ${ }^{80}$ In addition, hypercalcemia can cause renal insufficiency, neurologic injuries, and anorexia, whereas hyperphosphatemia caused vascular and soft-tissue calcifications. ${ }^{79}$

Demirkaya et al. ${ }^{11}$ used a dental extraction socket model to verify the effects of MTA Angelus, MTA Fillapex, and Theracal LC on aluminum levels in the plasma and liver at 7, 30, and 60 days. The authors reported that plasma aluminum levels were higher in the presence of MTA Angelus and MTA Fillapex; however, no differences in aluminum levels in liver samples were identified.

Furthermore, in another report, Demirkaya et al. ${ }^{64}$ examined the effects of MTA Angelus, MTA Fillapex, and Theracal LC on aluminum levels and oxidative stress parameters by analysis of thiobarbituric acid reactive substances (TBARS) levels and catalase (CAT), superoxide dismutase (SOD), and glutathione peroxidase (GPx) activities in the brain at 7,30 and 60 days. A transient increase in brain aluminum levels was detected in the MTA Angelus group at 7 days; in contrast, the MTA Fillapex and Theracal LC groups showed the highest levels only on day 60. Additionally, the TBARS levels and CAT, SOD, and GPx activities in brain were transiently upregulated at 7 days. Moreover, due to the aluminum neurotoxicity, the presence of this metal in brain tissue induces oxidative stress, which can be related to the pathogenesis of some neurological illnesses such as Alzheimer's disease and Parkinson's disease, ${ }^{81}$ as well as skeletal and hematological changes. ${ }^{82}$
In a complementary study, Demirkaya et al. ${ }^{73}$ evaluated if the oxidative stress parameters in erythrocytes and liver were altered in the presence of these same materials and showed that all sealers promoted a transient increase in TBARS levels, which is a biomarker of lipid peroxidation, and in the activity levels of antioxidant enzymes in erythrocytes and the liver. In addition, the MTA Angelus group showed the highest erythrocyte and liver TBARS concentrations at 7 days. It is important to highlight that induction of oxidative stress even with a transient increase can promote systemic effects, including dementia, Alzheimer's and Parkinson's disease, ${ }^{83}$ and variations in behavioral and cognitive function. ${ }^{84}$ Furthermore, the elevated levels of lipid peroxidation products are associated with atherosclerosis ${ }^{85}$ and kidney disease. ${ }^{86}$

Therefore, considering the fact that only a few investigations have been performed to assess the systemic effect of endodontic sealers, it is clear that further studies are necessary to elucidate their possible toxic effects, as this relationship is not yet completely understood.

\section{Systemic conditions and dental materials (Table 3)}

The connections/associations among AP, chronic inflammatory processes of infectious origin, and systemic diseases such as diabetes mellitus, cardiovascular disease, osteoporosis, alcoholism, liver disease, and coagulation disorders are well-known. ${ }^{13,14}$ Although the impact of these disorders on periapical healing has been investigated, there is little information available concerning the correlation between systemic conditions and oral diseases with regard to the pulpal healing behavior after endodontic procedures or even the tissue response to endodontic materials.

Independent of the systemic condition, dental materials should be biocompatible and have the ability to achieve healing. Some in vivo and in vitro studies have been developed to elucidate this relationship. ${ }^{48,87}$ In addition, animal models that simulate systemic conditions, such as diabetes mellitus and hypertension, have also been employed. ${ }^{48,87}$ 
- Endodontic medicine: interrelationships among apical periodontitis, systemic disorders, and tissue responses of dental materials

Table 3. Characteristics of the studies included in the Part II (b) - Systemic conditions and dental materials.

\begin{tabular}{|c|c|c|c|c|c|}
\hline Authors/year & Study type & Materials & Body organs & Analysis & Systemic Condition \\
\hline Garber et al. ${ }^{92}$ (2009) & Rats & MTA & Dental pulp & Histopathologic analysis & Diabetes Mellitus \\
\hline Madani et al. ${ }^{93}$ (2014) & Rats & $\begin{array}{l}\text { MTA } \\
\text { CEM }\end{array}$ & Dental pulp & Histopathologic analysis & Diabetes Mellitus \\
\hline Gomes-Filho et al. ${ }^{87}$ (2015) & Rats & MTA & Subcutaneous tissue & $\begin{array}{l}\text { Tissue response and } \\
\text { Mineralization ability }\end{array}$ & Diabetes Mellitus \\
\hline Gomes Filho et al ${ }^{94}$ (2016) & Rats & $\begin{array}{l}\text { MTA Fillapex } \\
\text { Sealapex }\end{array}$ & Subcutaneous tissue & $\begin{array}{l}\text { Tissue response and } \\
\text { Mineralization ability }\end{array}$ & Diabetes Mellitus \\
\hline Martins et al. ${ }^{101}$ (2016) & Rats & $\begin{array}{c}\text { Gray MTA Angelus } \\
\text { White MTA Angelus } \\
\text { IRM }\end{array}$ & Subcutaneous tissue & $\begin{array}{l}\text { Tissue response and } \\
\text { Mineralization ability }\end{array}$ & Hypertension \\
\hline Cintra et al..$^{95}$ (2017) & Rats & $35 \%$ hydrogen peroxide $\left(\mathrm{H}_{2} \mathrm{O}_{2}\right)$ & Dental pulp & Histopathologic analysis & \\
\hline Ferreira et al. ${ }^{96}$ (2017) & Rats & $35 \%$ hydrogen peroxide $\left(\mathrm{H}_{2} \mathrm{O}_{2}\right)$ & Dental pulp & $\begin{array}{c}\text { Immunohistochemistry } \\
\text { (IL-6, TNF- } \alpha, \text { IL-17) }\end{array}$ & \\
\hline Martins et al. ${ }^{103}$ (2018) & Rats & $\begin{array}{c}\text { Gray MTA Angelus } \\
\text { White MTA Angelus } \\
\text { IRM }\end{array}$ & Subcutaneous tissue & $\begin{array}{l}\text { Immunohistochemistry } \\
\text { (Runx-2, OCN, OPN) }\end{array}$ & Hypertension \\
\hline Queiroz et al. ${ }^{80}$ (2018) & Rats & $\begin{array}{l}\text { Gray MTA Angelus } \\
\text { White MTA Angelus }\end{array}$ & $\begin{array}{c}\text { Blood (plasma) } \\
\text { Subcutaneous tissue }\end{array}$ & $\begin{array}{c}\text { Biochemical analysis } \\
\text { (Ca, P, ALP) } \\
\text { Immunohistochemistry } \\
\text { (Runx-2, OCN, OPN) }\end{array}$ & Diabetes Mellitus \\
\hline
\end{tabular}

d. Diabetes and dental materials

Diabetes mellitus is a metabolic disease considered to be a modulator of endodontic infections, ${ }^{88}$ and it is responsible for altering the immune and inflammatory response, undermining the healing process, and promoting damage to body organs and tissues, including the dental pulp and periapical tissues. . $9,90,91^{2}$

Garber et al. ${ }^{92}$ verified the effect of hyperglycemia on pulpal healing in exposed rat pulpal tissue that was capped with MTA at 30 days and revealed an increase in pulp inflammation and inhibition of dentin bridge formation in diabetic rats, showing that the hyperglycemic state adversely affected pulpal healing. In another study, Madani et al. ${ }^{93}$ compared the effects of MTA or calcium-enriched mixture cement on dental pulp response to pulpcapping in diabetic rats. The authors analyzed the intensity of inflammation, dentin bridge formation, and dentin bridge continuity and reported an increase in the number of inflammatory cells under diabetic conditions; in addition, they identified differences in dentin bridge formation, dentin bridge continuity, and the number of inflammatory cells among the groups treated with MTA or calcium-enriched mixture. In contrast, since the diabetic rats treated with MTA did not exhibit a significantly higher inflammatory response in comparison to healthy controls, the authors suggested that MTA is a superior material for pulp therapy under diabetic conditions.

Gomes-Filho et al. ${ }^{87}$ investigated the effects of diabetes on the tissue response and mineralization ability of MTA and revealed that diabetes did not influence the tissue response to MTA or the mineralization stimulated by it. In addition, no evidence of the direct correlation among diabetes mellitus and inflammatory response or mineralization ability for Sealapex and MTA Fillapex sealers was detected in a similar investigation. ${ }^{94}$

Furthermore, the local and systemic effects of both Gray and White MTA on bone marker expression after subcutaneous implantation in diabetic rats were investigated by Queiroz et al..$^{80}$ Immunohistochemical analysis of osteocalcin and osteopontin production and biochemical analyses of calcium, phosphorus, and serum alkaline phosphatase levels at 7 and 30 days were performed. At day 7, calcium and phosphorus levels were higher in the GMTA group than in the WMTA group. At both time points, 
alkaline phosphatase activity was higher; moreover, an increase in phosphorus levels was observed at 30 days. Besides, under diabetic conditions, both MTAs had an inhibitory effect on osteocalcin and osteopontin production.

Although scientific evidence shows that hyperglycemia leads to an increase in inflammation and calcification and undermines dentin bridge formation on the dental pulp, ${ }^{91,92}$ the effect of dental bleaching procedures on the pulp under diabetic conditions remains unclear.

Cintra et al. ${ }^{95}$ examined the inflammatory response and maturation of collagen fibers in the pulp tissue of maxillary molars after dental bleaching with $35 \%$ hydrogen peroxide gel for 30 min in healthy and diabetic rats and reported an increase in the inflammatory response, a reduction in the pulp chamber area by deposition of reactionary dentine, and an increase in mature collagen fibers in the diabetic bleaching group. In a complementary study, the effect of tooth bleaching with $35 \%$ hydrogen peroxide gel on the production of the immunoregulatory cytokines IL-6, TNF- $\alpha$, and IL-17 in the pulp tissue under diabetic conditions was also evaluated by Ferreira et al. ${ }^{96}$ Irrespective of the diabetes condition, tooth bleaching increased IL-6 and TNF-a production. Nevertheless, higher levels of inflammation and TNF-a level were observed in diabetic rats. Regardless of IL-17 production, an increase was detected in the early periods in healthy rats.

e. Hypertension and dental materials

Hypertension is defined as a chronic and inflammatory disorder ${ }^{97}$ and is considered a risk factor for both oral and systemic disease. Chronic kidney failure, atherosclerosis, heart attack, stroke, cerebrovascular disease, and dementia ${ }^{98,99}$ as well

\section{References}

1. Gazivoda D, Dzopalic T, Bozic B, Tatomirovic Z, Brkic Z, Colic M. Production of proinflammatory and immunoregulatory cytokines by inflammatory cells from periapical lesions in culture. J Oral Pathol Med. 2009 Aug;38(7):605-11. https://doi.org/10.1111/j.1600-0714.2009.00788.x

2. Silva MJ, Kaiiya M, AlShwaimi E, Sasaki H, Hong J, $\mathrm{Ok} \mathrm{P}$ et al. Bacteria-reactive immune response may as periodontitis and apical periodontitis ${ }^{54,100,101}$ have been reported to be associated with hypertension. Although the relationship between hypertension and periapical lesions has been described, ${ }^{14,48}$ the effect of endodontic materials on pulp and periapical tissue under hypertensive conditions remains unclear.

Martins et al. ${ }^{101}$ evaluated the effect of hypertension on tissue response and the mineralization capacity of Gray MTA, White MTA, and IRM (intermediate restorative material) at 7 and 30 days and observed an intense inflammatory response in hypertensive rats in the presence of all sealers. Even under hypertensive conditions, both MTAs were capable of promoting mineralization; however, a decrease in the mineralization rate was detected in hypertensive rats. Thus, the authors suggested that hypertension could impair the tissue response and mineralization ability of MTA.

Since hypertension is associated with alterations in bone metabolism and a reduction in bone mineral density and mineralization ability due to the calcium loss in bones, ${ }^{102}$ Martins et al. ${ }^{103}$ investigated the mineralization ability of both Gray and White MTA and IRM sealers implanted on the subcutaneous tissue of normal and hypertensive rats. Immunohistochemical analysis of osteoblastic biomarkers showed a decrease in the production of the RUNX-2, OCN and OPN biomarkers in the presence of both MTAs under hypertensive conditions. Further, regardless of the systemic condition, no biomarker production was observed in the IRM group.

Considering the fact that there is only limited information concerning the links between systemic conditions and endodontic materials, it is evident that more research should be conducted to elucidate this relationship, including the possible systemic effects.

\footnotetext{
induce RANKL-expressing $\mathrm{T}$ cells in the mouse periapical bone loss lesion. J Endod. 2012 Mar;38(3):346-50.

https://doi.org/10.1016/i.joen.2011.12.029

3. Azuma MM, Gomes-Filho JE, Ervolino E, Cardoso CBM, Pipa $C B$, Kawai T et al. Omega-3 fatty acids reduce inflammation in rat apical periodontitis. J Endod. 2018 Apr;44(4):604-8. https://doi.org/10.1016/i.joen.2017.12.008
} 
- Endodontic medicine: interrelationships among apical periodontitis, systemic disorders, and tissue responses of dental materials

4. Liliestrand JM, Mäntylä P, Paju S, Buhlin K, Kopra KA, Persson $G R$ et al. Association of endodontic lesions with coronary artery disease. J Dent Res. 2016 Nov;95(12):1358-65. https://doi.org/10.1177/0022034516660509

5. Samuel RO, Gomes-Filho JE, Azuma MM, Sumida $\mathrm{DH}$, Oliveira SH, Chiba FY et al. Endodontic infections increase leukocyte and lymphocyte levels in the blood. Clin Oral Investig. 2018 Apr;22(3):1395-401. https://doio.org/10.1007/s00784-017-2222-z.

6. Prieto AK, Gomes-Filho JE, Azuma MM, Sivieri-Araújo G, Narciso LG, Souza JC et al. Influence of apical periodontitis on stress oxidative parameters in diabetic rats. J Endod. 2017 Oct;43(10):1651-6. https://doi.org/10.1016/i.joen.2017.05.014

7. Cintra LT, Samuel RO, Azuma MM, Queiróz AO, Ervolino $\mathrm{E}$, Sumida $\mathrm{DH}$ et al. Multiple apical periodontitis influences serum levels of cytokines and nitric oxide. J Endod. 2016 May;42(5):747-51. https://doi.org/10.1016/i.joen.2016.01.022

8. Pinheiro SL, Araujo G, Bincelli I, Cunha R, Bueno C. Evaluation of cleaning capacity and instrumentation time of manual, hybrid and rotary instrumentation techniques in primary molars. Int Endod J. 2012 Apr;45(4):379-85. https://doi.org/10.1111/j.1365-2591.2011.01987.x

9. Gomes-Filho JE, Gomes BP, Zaia AA, Ferraz CR, Souza-Filho FJ. Evaluation of the biocompatibility of root canal sealers using subcutaneous implants. J Appl Oral Sci. 2007 Jun;15(3):186-94. https://doi.org/10.1590/S1678-77572007000300007

10. Saxena P, Gupta SK, Newaskar V. Biocompatibility of rootend filling materials: recent update. Restor Dent Endod. 2013 Aug;38(3):119-27. https://doi.org/10.5395/rde.2013.38.3.119

11. Demirkaya K, Can Demirdöğen B, Öncel Torun Z, Erdem $\mathrm{O}$, Çetinkaya S, Akay C. In vivo evaluation of the effects of hydraulic calcium silicate dental cements on plasma and liver aluminium levels in rats. Eur J Oral Sci. 2016 Feb;124(1):75-81. https://doi.org/10.1111/eos.12238

12. Simsek N, Bulut ET, Ahmetoğlu F, Alan H. Determination of trace elements in rat organs implanted with endodontic repair materials by ICP-MS. J Mater Sci Mater Med. 2016 Mar;27(3):46. https://doi.org/10.1007/s10856-015-5663-4

13. Segura-Egea JJ, Martín-González J, Castellanos-Cosano L. Endodontic medicine: connections between apical periodontitis and systemic diseases. Int Endod J. 2015 Oct;48(10):933-51. https://doi.org/10.1111/iej.12507

14. Sasaki $H$, Hirai K, Martins $C M$, Furusho $H$, Battaglino R, Hashimoto K. Interrelationship between periapical lesion and systemic metabolic disorders. Curr Pharm Des. 2016;22(15):2204-15. https://doi.org/10.2174/1381612822666160216145107

15. Schutte RJ, Xie L, Klitzman B, Reichert WM In vivo cytokine-associated responses to biomaterials. Biomaterials. 2009 Jan;30(2):160-8. https://doi.org/10.1016/i.biomaterials.2008.09.026

16. Reyes-Carmona JF, Santos AS, Figueiredo CP, Baggio $\mathrm{CH}$, Felippe MC, Felippe WT et al. Host-mineral trioxide aggregate inflammatory molecular signaling and biomineralization ability. J Endod. 2010 Aug;36(8):1347-53. https://doi.org/10.1016/i.joen.2010.04.029

17. Schulze A, Schönauer $M$, Busse M. Sudden improvement of insulin sensitivity related to an endodontic treatment. J Periodontol. 2007 Dec;78(12):2380-4. https://doi.org/10.1902/jop.2007.070033

18. Sánchez-Domínguez B, López-López J, JanéSalas E, Castellanos-Cosano L, Velasco-Ortega E, Segura-Egea JJ. Glycated hemoglobin levels and prevalence of apical periodontitis in type 2 diabetic patients. J Endod. 2015 May;41(5):601-6. https://doi.org/10.1016/i.joen.2014.12.024

19. Arya S, Duhan J, Tewari S, Sangwan P, Ghalaut V, Aggarwal $\mathrm{S}$. Healing of apical periodontitis after nonsurgical treatment in patients with type 2 diabetes. J Endod. 2017 Oct;43(10):1623-7. https://doi.org/10.1016/i.joen.2017.05.013

20. Astolphi RD, Curbete MM, Colombo NH, Shirakashi DJ, Chiba $\mathrm{FY}$, Prieto AK et al. Periapical lesions decrease insulin signal and cause insulin resistance. J Endod. 2013 May;39(5):648-52. https://doi.org/10.1016/i.joen.2012.12.031

21. Astolphi RD, Curbete MM, Chiba FY, Cintra LT, Ervolino E, Mota MS et al. Periapical lesions decrease insulin signaling in rat skeletal muscle. J Endod. 2015 Aug;41(8):1305-10. https://doi.org/10.1016/i.joen.2015.04.002

22. Pereira RF, Cintra LT, Tessarin GW, Chiba FY, Mattera MSLC, Scaramele NF, et al. Periapical lesions increase macrophage infiltration and inflammatory signaling in muscle tissue of rats. J Endod. 2017 Jun;43(6):982-8. https://doi.org/10.1016/i.joen.2017.01.030

23. Zhang J, Huang X, Lu B, Zhang C, Cai Z. Can apical periodontitis affect serum levels of CRP, IL-2, and IL-6 as well as induce pathological changes in remote organs? Clin Oral Investig. 2016 Sep;20(7):1617-24. https://doi.org/10.1007/s00784-015-1646-6

24. Inchingolo F, Marrelli M, Annibali S, Cristalli MP, Dipalma $G$, Inchingolo AD et al. Influence of endodontic treatment on systemic oxidative stress. Int J Med Sci. 2013 Dec;11(1):1-6. https://doi.org/10.7150/ijms.6663

25. Halliwell B, Whiteman M. Measuring reactive species and oxidative damage in vivo and in cell culture: how should you do it and what do the results mean? Br J Pharmacol. 2004 May;142(2):231-55. https://doi.org/10.1038/sj.bjp.0705776

26. Kohsaka T, Kumazawa M, Yamasaki M, Nakamura $\mathrm{H}$. Periapical lesions in rats with streptozotocininduced diabetes. J Endod. 1996 Aug;22(8):418-21. https://doi.org/10.1016/S0099-2399(96)80243-3

27. Iwama A, Nishigaki N, Nakamura K, Imaizumi I, Shibata $\mathrm{N}$, Yamasaki $\mathrm{M}$ et al. The effect of high sugar intake on the development of periradicular lesions in rats with type 2 diabetes. J Dent Res. 2003 Apr;82(4):322-5. https://doi.org/10.1177/154405910308200416

28. Cintra LT, Samuel RO, Facundo AC, Prieto AK, Sumida DH, Bomfim SR et al. Relationships between oral infections and blood glucose concentrations or $\mathrm{HbAlc}$ levels in normal 
and diabetic rats. Int Endod J. 2014 Mar;47(3):228-37.

https://doi.org/10.1111/iej.12136

29. Cintra LT, Facundo ACS, Prieto AK, Sumida DH, Narciso

LG, Mogami Bomfim SR et al. Blood profile and histology in oral infections associated with diabetes. J Endod. 2014 Aug;40(8):1139-44. https://doi.org/10.1016/i.joen.2014.01.034

30. Cintra LT, Samuel RO, Azuma MM, Ribeiro CP, Narciso LG, Lima VM et al. Apical periodontitis and periodontal disease increase serum IL-17 levels in normoglycemic and diabetic rats. Clin Oral Investig. 2014 Dec;18(9):2123-8. https://doi.org/10.1007/s00784-014-1192-7

31. Azuma MM, Gomes-Filho JE, Prieto AK, Samuel RO, Lima VM, Sumida DH et al. Diabetes increases interleukin-17 levels in periapical, hepatic, and renal tissues in rats. Arch Oral Biol. $2017 \mathrm{Nov} ; 83: 230-5$. https://doi.org/10.1016/i.archoralbio.2017.08.001

32. Segura-Egea JJ, Jiménez-Pinzón A, Ríos-Santos JV, Velasco-Ortega E, Cisneros-Cabello R, Poyato-Ferrera M. High prevalence of apical periodontitis amongst type 2 diabetic patients. Int Endod J. 2005 Aug;38(8):564-9. https://doi.org/10.1111/j.1365-2591.2005.00996.x

33. López-López J, Jané-Salas E, Estrugo-Devesa A, VelascoOrtega E, Martín-González J, Segura-Egea JJ. Periapical and endodontic status of type 2 diabetic patients in Catalonia, Spain: a cross-sectional study. J Endod. 2011 May;37(5):598-601. https://doi.org/10.1016/i.joen.2011.01.002

34. Marotta PS, Fontes TV, Armada L, Lima KC, Rôças IN, Siqueira Junior JF. Type 2 diabetes mellitus and the prevalence of apical periodontitis and endodontic treatment in an adult Brazilian population. J Endod. 2012 Mar;38(3):297-300. https://doi.org/10.1016/i.joen.2011.11.001

35. Smadi L. Apical Periodontitis and endodontic treatment in patients with type ii diabetes mellitus: comparative crosssectional survey. J Contemp Dent Pract. 2017 May; 18(5):35862. https://doi.org/10.5005/ip-journals-10024-2046

36. Tibúrcio-Machado CD, Bello MC, Maier J, Wolle CF, Bier CA. Influence of diabetes in the development of apical periodontitis: a critical literature review of human studies. J Endod. 2017 Mar;43(3):370-6. https://doi.org/10.1016/i.joen.2016.11.012

37. Rudranaik $S$, Nayak $M$, Babshet $M$. Periapical healing outcome following single visit endodontic treatment in patients with type 2 diabetes mellitus. J Clin Exp Dent. 2016 Dec;8(5):e498-504. https://doi.org/10.4317/jced.52859

38. Fouad AF, Burleson J. The effect of diabetes mellitus on endodontic treatment outcome: data from an electronic patient record. J Am Dent Assoc. 2003 Jan;134(1):43-51. https://doi.org/10.14219/jada.archive.2003.0016

39. Britto LR, Katz J, Guelmann M, Heft M. Periradicular radiographic assessment in diabetic and control individuals. Oral Surg Oral Med Oral Pathol Oral Radiol Endod. 2003 Oct;96(4):449-52. https://doi.org/10.1016/S1079-2104(03)00034-9

40. Segura-Egea JJ, Martín-González J, Cabanillas-Balsera D, Fouad AF, Velasco-Ortega E, López-López J. Association between diabetes and the prevalence of radiolucent periapical lesions in root-filled teeth: systematic review and meta-analysis. Clin Oral Investig. 2016 Jul;20(6):1133-41. https://doi.org/10.1007/s00784-016-1805-4

41. Cintra LT, Facundo ACS, Azuma MM, Sumida DH, Astolphi RD, Bomfim SR et al. Pulpal and periodontal diseases increase triglyceride levels in diabetic rats. Clin Oral Investig. 2013 Jul;17(6):1595-9. https://doi.org/10.1007/s00784-012-0853-7

42. Ferreira LL, Gomes JE, Sumida DH, Bonfim SR, SivieriAraújo $G$, Guimarães $G$ et al. Diabetic rats present high mean platelet count in the presence of oral infections. Braz Dent J. 2017 Sep-Oct;28(5):548-51. https://doi.org/10.1590/0103-6440201701386

43. Cintra LT, Samuel RO, Prieto AK, Sumida DH, DezanJúnior E, Gomes-Filho JE. Oral health, diabetes, and body weight. Arch Oral Biol. 2017 Jan;73:94-9. https://doi.org/10.1016/i.archoralbio.2016.10.002

44. Singhal RK, Rai B. sTNF-R Levels: Apical periodontitis linked to coronary heart disease. Open Access Maced J Med Sci. 2017 Mar;5(1):68-71. https://doi.org/10.3889/oamims.2017.010

45. Pasqualini D, Bergandi L, Palumbo L, Borraccino A, Dambra $V$, Alovisi $M$ et al. Association among oral health, apical periodontitis, CD14 polymorphisms, and coronary heart disease in middle-aged adults. J Endod. 2012 Dec;38(12):1570-7. https://doi.org/10.1016/i.joen.2012.08.013

46. Caplan DJ, Chasen JB, Krall EA, Cai J, Kang S, Garcia $\mathrm{Rl}$ et al. Lesions of endodontic origin and risk of coronary heart disease. J Dent Res. 2006 Nov;85(11):996-1000. https://doi.org/10.1177/154405910608501104

47. Rashmi N, Galhotra V, Goel P, Rajguru JP, Jha SK, Kulkarni $K$. Assessment of $C$-reactive proteins, cytokines, and plasma protein levels in hypertensive patients with apical periodontitis. J Contemp Dent Pract. 2017 Jun; 18(6):516-21. https://doi.org/10.5005/ip-journals-10024-2076

48. Martins CM, Sasaki H, Hirai K, Andrada AC, Gomes-Filho JE. Relationship between hypertension and periapical lesion: an in vitro and in vivo study. Braz Oral Res. 2016 Oct;30(1):e78. https://doi.org/10.1590/1807-3107BOR-2016.vol30.0078

49. Gomes MS, Hugo FN, Hilgert JB, Sant'Ana Filho M, Padilha DM, Simonsick EM et al. Apical periodontitis and incident cardiovascular events in the Baltimore longitudinal study of ageing. Int Endod J. 2016 Apr;49(4):334-42. https://doi.org/10.1111/iej.12468

50. Costa TH, Figueiredo Neto JA, Oliveira AE, Maia MFL, Almeida AL. Association between chronic apical periodontitis and coronary artery disease. J Endod. 2014 Feb;40(2):164-7. https://doi.org/10.1016/i.joen.2013.10.026

51. An GK, Morse DE, Kunin M, Goldberger RS, Psoter WJ. Association of radiographically diagnosed apical periodontitis and cardiovascular disease: a hospital records-based study. J Endod. 2016 Jun;42(6):916-20. https://doi.org/10.1016/i.joen.2016.03.011

52. Virtanen E, Nurmi T, Söder PÖ, Airila-Månsson S, Söder B, Meurman JH. Apical periodontitis associates 
- Endodontic medicine: interrelationships among apical periodontitis, systemic disorders, and tissue responses of dental materials

with cardiovascular diseases: a cross-sectional study

from Sweden. BMC Oral Health. 2017 Jul;17(1):107.

https://doi.org/10.1186/s12903-017-0401-6

53. Segura-Egea JJ, Jimenez-Moreno E, Calvo-Monroy C, RíosSantos JV, Velasco-Ortega E, Sánchez-Domínguez B et al. Hypertension and dental periapical condition. J Endod. 2010 Nov;36(11):1800-4. https://doi.org/10.1016/i.joen.2010.08.004

54. Segura-Egea JJ, Castellanos-Cosano L, Velasco-Ortega E, Ríos-Santos JV, Llamas-Carreras JM, Machuca G et al. Relationship between smoking and endodontic variables in hypertensive patients. J Endod. 2011 Jun;37(6):764-7. https://doi.org/10.1016/i.joen.2011.03.004

55. Joshipura KJ, Wand HC, Merchant AT, Rimm EB. Periodontal disease and biomarkers related to cardiovascular disease. J Dent Res. 2004 Feb;83(2):151-5. https://doi.org/10.1177/154405910408300213

56. Khalighinejad N, Aminoshariae A, Kulild JC, Sahly K, Mickel A. Association of end-stage renal disease with radiographically and clinically diagnosed apical periodontitis: a hospital-based study. J Endod. 2017 Sep;43(9):1438-41. https://doi.org/10.1016/i.joen.2017.04.014PMID:28712633

57. Khalighinejad N, Aminoshariae A, Kulild JC, Mickel A. Apical periodontitis, a predictor variable for preeclampsia: a case-control study. J Endod. 2017 Oct;43(10):1611-4. https://doi.org/10.1016/i.joen.2017.05.021

58. Piras V, Usai P, Mezzena S, Susnik M, Ideo F, Schirru E et al. Prevalence of apical periodontitis in patients with inflammatory bowel diseases: a retrospective clinical study. J Endod. 2017 Mar;43(3):389-94. https://doi.org/10.1016/i.joen.2016.11.004

59. Grønkjær L, Holmstrup P, Schou S, Schwartz K, Kongstad J, Jepsen $\mathrm{P}$ et al. Presence and consequence of tooth periapical radiolucency in patients with cirrhosis. Hepat Med. 2016 Sep;8:97-103. https://doi.org/10.2147/HMER.S113485

60. Gomes-Filho JE, Wayama MT, Dornelles RC, Ervolino E, Yamanari GH, Lodi CS et al. Raloxifene modulates regulators of osteoclastogenesis and angiogenesis in an oestrogen deficiency periapical lesion model. Int Endod J. 2015 Nov;48(11):1059-68. https://doi.org/10.1111/iej.12403

61. Gomes-Filho JE, Wayama MT, Dornelles RC, Ervolino E, Coclete GA, Duarte PC et al. Effect of raloxifene on periapical lesions in ovariectomized rats. J Endod. 2015 May;41(5):671-5. https://doi.org/10.1016/i.joen.2014.11.027

62. Ballestri M, Baraldi A, Gatti AM, Furci L, Bagni A, Loria $P$ et al. Liver and kidney foreign bodies granulomatosis in a patient with malocclusion, bruxism, and worn dental prostheses. Gastroenterology. 2001 Nov;121(5):1234-8. https://doi.org/10.1053/gast.2001.29333

63. Schedle A, Ortengren U, Eidler N, Gabaver M, Hensten A. Do adverse effects of dental materials exist? What are the consequences, and how can they be diagnosed and treated? Clin Oral Implants Res. 2007 Jun;18(3 Suppl 3):232-56. https://doi.org/10.1111/j.1600-0501.2007.01481.x

64. Demirkaya K, Demirdöğen BC, Torun ZÖ, Erdem O, Çırak E, Tunca YM. Brain aluminium accumulation and oxidative stress in the presence of calcium silicate dental cements. Hum Exp Toxicol. 2017 Oct;36(10):1071-80. https://doi.org/10.1177/0960327116679713

65. Khalil WA, Eid NF. Biocompatibility of bioaggregate and mineral trioxide aggregate on the liver and kidney. Int Endod J. 2013 Aug;46(8):730-7. https://doi.org/10.1111/iej.12050

66. Garcia LD, Huck C, Magalhães FA, Souza PP, Costa CAS. Systemic effect of mineral aggregatebased cements: histopathological analysis in rats. J Appl Oral Sci. 2017 Nov-Dec;25(6):620-30. https://doi.org/10.1590/1678-7757-2016-0634

67. Al-Hiyasat AS, Darmani H, Elbetieha AM. Effects of resin based dental composites on fertility of male mice. Eur J Oral Sci. 2002 Feb;110(1):44-7. https://doi.org/10.1034/j.1600-0722.2002.00163.x

68. Fakhouri J, Sarkis R, Chababi-Atallah M, Aftimos G. Toxic effects of methyl methacrylate monomer on male genital tissues: in vitro study in rats. J Med Liban. 2008 Jan-Mar;56(1):22-6.

69. Elovaara $E$, Kivistö $H$, Vainio $H$. Effects of methyl methacrylate on non-protein thiols and drug metabolizing enzymes in rat liver and kidneys. Arch Toxicol. 1983 Feb;52(2):109-21. https://doi.org/10.1007/BF00354771

70. Raje RR, Ahmad S, Weisbroth SH. Methylmethacrylate: tissue distribution and pulmonary damage in rats following acute inhalation. Res Commun Chem Pathol Pharmacol. 1985 Oct;50(1):151-4. https://doi.org/10.1016/0378-4274(83)90539-8

71. Chang SW, Baek SH, Yang HC, Seo DG, Hong ST, Han SH et al. Heavy metal analysis of ortho MTA and ProRoot MTA. J Endod. 2011 Dec;37(12):1673-6. https://doi.org/10.1016/i.joen.2011.08.020

72. Kum KY, Kim EC, Yoo YJ, Zhu Q, Safavi K, Bae KS et al. Trace metal contents of three tricalcium silicate materials: MTA Angelus, Micro Mega MTA and Bioaggregate. Int Endod J. 2014 Jul;47(7):704-10. https://doi.org/10.1111/iej.12208

73. Demirkaya K, Demirdöğen BC, Torun ZO, Erdem O, Tunca YM. The effects of hydraulic calcium silicate containing endodontic materials on oxidative stress in erythrocytes and liver. Turkish J Biochem. 2017. https://doi.org/10.1515/tib-2016-0263.

74. Hoppe A, Güldal NS, Boccaccini AR. A review of the biological response to ionic dissolution products from bioactive glasses and glass-ceramics. Biomaterials. 2011 Apr;32(11):2757-74 https://doi.org/10.1016/i.biomaterials.2011.01.004

75. Tian J, Zhang Y, Lai Z, Li M, Huang Y, Jiang $\mathrm{H}$ et al. lon Release, Microstructural, and Biological Properties of iRoot BP Plus and ProRoot MTA Exposed to an Acidic Environment. J Endod. 2017 Jan;43(1):163-8. https://doi.org/10.1016/i.joen.2016.10.011

76. Economides N, Kotsaki-Kovatsi VP, Poulopoulos A, Kolokuris I, Rozos G, Shore R. Experimental study of the biocompatibility of four root canal sealers and their influence on the zinc and calcium content of several tissues. J Endod. 1995 Mar;21(3):1227. https://doi.org/10.1016/S0099-2399(06)80436-X

77. Kolokouris I, Kotsaki-Kovatsi VP, Economides N, Poulopoulos A, Rozos G, Vlemmas I. Influence of zinc oxide and eugenol 
sealer on concentration of zinc, calcium and copper in rat tissues. Endod Dent Traumatol. 1998 Oct;14(5):210-3. https://doi.org/10.1111/j.1600-9657.1998.tb00840.x

78. Wang Y, Su H, Gu Y, Song X, Zhao J. Carcinogenicity of chromium and chemoprevention: a brief update. OncoTargets Ther. 2017 Aug;10:4065-79. https://doi.org/10.2147/OTT.S139262

79. Chang WT, Radin B, McCurdy MT. Calcium, magnesium, and phosphate abnormalities in the emergency department. Emerg Med Clin North Am. 2014 May;32(2):349-66. https://doi.org/10.1016/i.emc.2013.12.006

80. Queiroz IOA, Mello WG, Martins CM, Dal Fabbro R, Narciso LG, Massunari L et al. Systemic bone marker expression induced by grey and white mineral trioxide aggregate in normal and diabetic conditions. Int Endod J. 2018 Jan 19. https://doi.org/10.1111/iej.12900

81. Kumar V, Gill KD. Oxidative stress and mitochondrial dysfunction in aluminium neurotoxicity and its amelioration: a review. Neurotoxicology. 2014 Mar;41:154-66. https://doi.org/10.1016/i.neuro.2014.02.004

82. Nayak P. Aluminum: impacts and disease. Environ Res. 2002 Jun;89(2):101-15. https://doi.org/10.1006/enrs.2002.4352

83. Cristalli DO, Arnal N, Marra FA, Alaniz MJ, Marra CA. Peripheral markers in neurodegenerative patients and their first-degree relatives. J Neurol Sci. 2012 Mar;314(1-2):48-56. https://doi.org/10.1016/i.jns.2011.11.001

84. Iguchi Y, Kosugi S, Nishikawa H, Lin Z, Minabe Y, Toda S. Repeated exposure of adult rats to transient oxidative stress induces various long-lasting alterations in cognitive and behavioral functions. PLoS One. 2014 Dec;9(12):e114024. https://doi.org/10.1371/journal.pone.0114024

85. Leonarduzzi G, Gamba P, Gargiulo S, Biasi F, Poli G. Inflammation-related gene expression by lipid oxidationderived products in the progression of atherosclerosis. Free Radic Biol Med. 2012 Jan;52(1):19-34. https://doi.org/10.1016/j.freeradbiomed.2011.09.031

86. Agarwal R. Chronic kidney disease is associated with oxidative stress independent of hypertension. Clin Nephrol. 2004 Jun;61(6):377-83. https://doi.org/10.5414/CNP61377

87. Gomes-Filho JE, Queiroz IOA, Watanabe S, Santos LMS, Lodi CS, Okamoto R et al. Influence of diabetes mellitus on tissue response to MTA and its ability to stimulate mineralization. Dent Traumatol. 2015 Feb;31(1):67-72. https://doi.org/10.1111/edt.12130

88. Fouad AF. Diabetes mellitus as a modulating factor of endodontic infections. J Dent Educ. 2003 Apr;67(4):459-67.

89. Delamaire M, Maugendre D, Moreno M, Le Goff MC, Allannic $\mathrm{H}$, Genetet B. Impaired leucocyte functions in diabetic patients. Diabet Med. 1997 Jan;14(1):29-34. https://doi.org/10.1002/ (SICI)1096-9136(199701)14:1<29::AID-DIA300>3.0.CO;2-V

90. lacopino AM. Periodontitis and diabetes interrelationships: role of inflammation. Ann Periodontol. 2001 Dec;6(1):125-37. https://doi.org/10.1902/annals.2001.6.1.125
91. Leite MF, Ganzerla E, Marques MM, Nicolau J. Diabetes induces metabolic alterations in dental pulp. J Endod. 2008 Oct;34(10):1211-4. https://doi.org/10.1016/i.joen.2008.07.010

92. Garber SE, Shabahang S, Escher AP, Torabinejad $M$. The effect of hyperglycemia on pulpal healing in rats. J Endod. 2009 Jan;35(1):60-2. https://doi.org/10.1016/i.joen.2008.09.010

93. Madani ZS, Haddadi A, Mesgarani A, Seyedmaiidi M, Mostafazadeh A, Bijani A et al. Histopathologic responses of the dental pulp to calcium-enriched mixture (CEM) and mineral trioxide aggregate (MTA) in diabetic and non-diabetic rats. Int J Mol Cell Med. 2014;3(4):263-71.

94. Gomes-Filho JE, Queiroz ÍO, Watanabe S, Cintra $L T$, Ervolino E. Influence of diabetes mellitus on the mineralization ability of two endodontic materials. Braz Oral Res. 2016;30(1):S1806-83242016000100218. https://doi.org/10.1590/1807-3107BOR-2016.vol30.0025

95. Cintra LT, Ferreira LL, Benetti F, Gastélum AA, Gomes-Filho $J E$, Ervolino E, et al. The effect of dental bleaching on pulpal tissue response in a diabetic animal model. Int Endod J. 2017 Aug;50(8):790-8. https://doi.org/10.1111/iej.12692

96. Ferreira LL, Gomes-Filho JE, Benetti F, Carminatti M, Ervolino $E$, Briso AL et al. The effect of dental bleaching on pulpal tissue response in a diabetic animal model: a study of immunoregulatory cytokines. Int Endod J. 2018 Mar;51(3):34756. https://doi.org/10.1111/iej.12852

97. Carretero OA, Oparil S. Essential hypertension. Part I: definition and etiology. Circulation. 2000 Jan;101(3):329-35. https://doi.org/10.1161/01.CIR.101.3.329

98. Lionakis N, Mendrinos D, Sanidas E, Favatas G, Georgopoulou M. Hypertension in the elderly. World J Cardiol. 2012 May;4(5):135-47. https://doi.org/10.4330/wjc.v4.i5.135

99. Norlander AE, Madhur MS, Harrison DG. The immunology of hypertension. J Exp Med. 2018 Jan;215(1):21-33. https://doi.org/10.1084/jem.20171773

100. Leite CL, Redins CA, Vasquez EC, Meyrelles SS. Experimentalinduced periodontitis is exacerbated in spontaneously hypertensive rats. Clin Exp Hypertens. 2005 Aug;27(6):523-31. https://doi.org/10.1081/CEH-200067688

101. Martins CM, Gomes-Filho JE, de Azevedo Queiroz ÍO, Ervolino E, Cintra LT. Hypertension undermines mineralizationinducing capacity of and tissue response to mineral trioxide aggregate endodontic cement. J Endod. 2016 Apr;42(4):604-9. https://doi.org/10.1016/i.joen.2016.01.003

102. Ye Z, Lu H, Liu P. Association between essential hypertension and bone mineral density: a systematic review and meta-analysis. Oncotarget. 2017 Aug;8(40):68916-27. https://doi.org/10.18632/oncotarget.20325

103. Martins CM, Queiroz IOA, Ervolino E, Cintra LT, GomesFilho JE. RUNX-2, OPN and OCN expression induced by grey and white mineral trioxide aggregate in normal and hypertensive rats. Int Endod J. 2018 Jun;51 (6):641-8. https://doi.org/10.1111/iej.12876 